\title{
Bedrock Investigation using Resistivity Method as an effort to Provide Subsurface Data at ITERA Campus
}

\author{
Rizka $^{1}$, S Satiawan ${ }^{1}$ \\ ${ }^{1}$ Geophysical Engineering Program, Terusan Ryacudu Boulevard Way Hui Jati Agung \\ Lampung Selatan, 35365 Indonesia
}

\begin{abstract}
This is a study of the application of resistivity method to provide the subsurface data for building/ foundation construction. The subsurface data which provided is resistivity data laterally and vertically and able to be used to investigate the depth and thickness of bedrock. 35 points of $1 \mathrm{D}$ resistivity data had been collected in ITERA campus that covered $\pm 150 \mathrm{Ha}$. It concentrates at northern to middle part of ITERA campus. Schlumberger configuration was employed with minimum and maximum $\mathrm{AB} / 2$ was 2 and 150 meter respectively and 3 varied MN. Iso-resistivity maps show high apparent resistivity value was distributed laterally and vertically. High apparent resistivity value is indicated as a representative of bedrock. The high apparent resistivity zone (resistive zone) was shown in Iso-resistivity map $A B / 22.5$ and consistently up to $\mathrm{AB} / 215$ with the range of high apparent resistivity value is 80.2 up to 210.8 ohmmeter. The resistive zone was distributed laterally in Northeast to West part of study area where the depth and thickness of bedrock in west part is shallower and thicker than others.
\end{abstract}

\section{Introduction}

ITERA is one of the new universities in Indonesia which is expected to give a contribution in empowering the potential that exist in Sumatera through excellence in the fields of science, technology, art and humanity. It is stated clearly in mission of ITERA and seems in the working plan of ITERA. Moreover, ITERA also is anticipated to speed up the quality of university in a decade, therefore supporting in facilities and infrastructure is really necessary in order to achieve the target which is entrusted to ITERA. Lecture and laboratory building are one of the infrastructures needed by ITERA besides the others. In order to optimize the construction of building and other physical infrastructures such as road, pedestrian, pool, garden, etc, so the information of subsurface should be revealed. Subsurface information could be categorized as crucial information/data to optimize the construction of infrastructure as well as in regional development.

Bedrock information is one of subsurface data which could be utilized in building construction work. Bedrock has close association with the foundation of a building. Foundation of a building is a crucial factor from a building since the foundation continues the building load to the soil. The building will not be influenced significantly once the building load is less than the ultimate bearing capacity of the soil. However vice versa, the building will be collapsed if the building loads higher than the ultimate bearing capacity of soil. Therefore, the selection or placement of a foundation on good quality bedrock could maintain the stability, sturdiness, and strength of a building. In other words, bedrock could influence the quality of a building [1].

Since ITERA is developing university and still needs the infrastructure particularly lecture building and laboratory, then the infrastructure construction is still carrying out in ITERA for the next few years. In order to provide the planning and construction teams the subsurface data/information, the 
resistivity survey had been deployed in ITERA campus and covered of area survey approximately 150 Ha. The resistivity survey was deployed in northern to middle part of ITERA campus. The chosen of northern to middle part as the study area since the lecture and laboratory building was planned will be constructed in this area. Therefore the main goal of this survey is to map the subsurface of ITERA campus laterally and vertically based on the resistivity value. It is expected, the resistivity value from the field survey could be used to investigate and determine the distribution of the bedrock laterally and vertically, quality of the bedrock, depth of bedrock, thickness of the bedrock and the lithology of the bedrock.

\section{Resistivity method}

Resistivity method is one of geophysics method to investigate the subsurface condition based on resistivity value of the subsurface. The principle of this method is injecting the current from surface to subsurface by using a transmitter (stainless steel electrode) and record the potential of the subsurface by using a receiver (copper electrode/ porous spot) [2]. Basically, the injected current will flow to the rock/soil through the pore or mineral of the rock/soil. Once, the current is flowing easily in a rock/soil then the rock/ soil has conductive properties and vice versa [3]. When the current is flowing quite difficult in a rock/soil then the rock/soil has resistive properties [4]. Consequently, resistivity method could be applied to several cases i.e. mineral and mining, environmental investigation, groundwater detection, and geotechnical matter [5].

Generally, resistivity survey is carried out by using 4 electrodes ( 2 current electrodes and 2 potential electrodes). There are several types of resistivity survey configuration namely wenner, schlumberger, dipole-dipole, pole-pole, and pole dipole. The chosen of configuration is based on the objective of the survey. There are three techniques of resistivity survey and it is close related to the objectives as well as the configuration. Mapping, sounding, and imaging are the three techniques in resistivity survey and has a quite different each other. Mapping is commonly used to study the variation of subsurface resistivity laterally whilst sounding is employed to know the variation vertically and imaging is used to know the variation both (laterally and vertically).

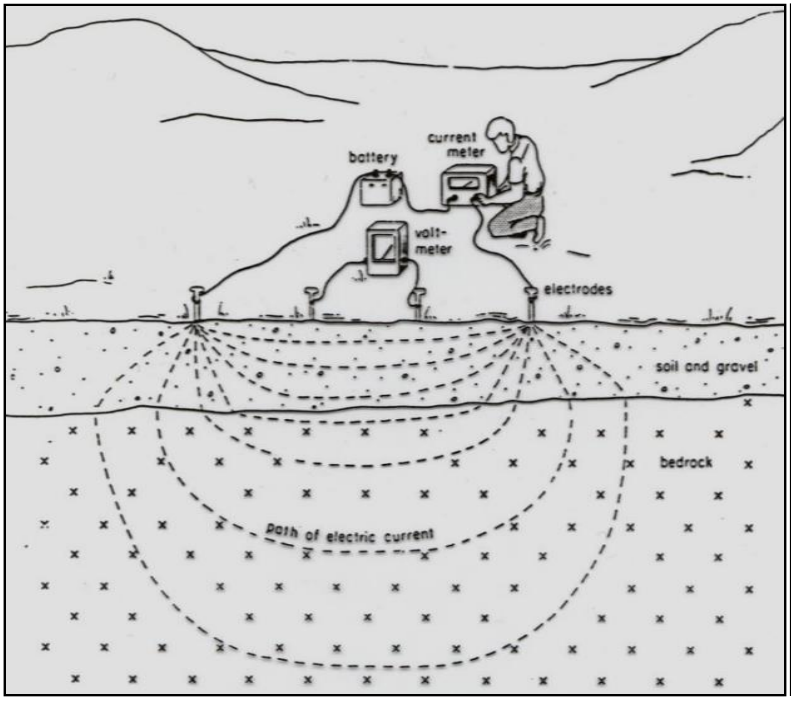

Figure 1. Ilustration of resistivity survey by using 4 electrodes.

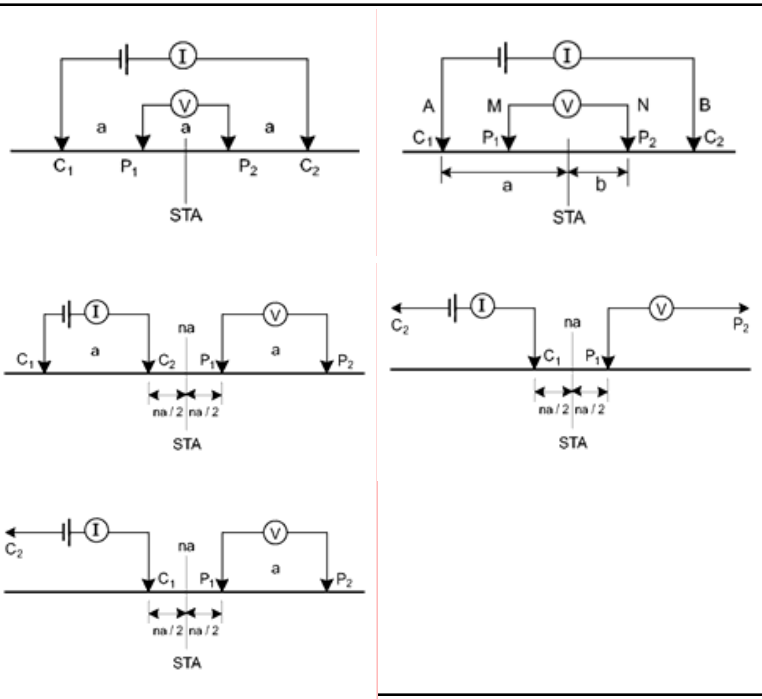

Figure 2. 5 Types of resistivity configuration which is commonly used

\subsection{Vertical Electrical Sounding (VES)}

Resistivity sounding is the study to Vertical Electrical Sounding (VES) is a method that studies vertical variations in subsurface rock resistivity [6]. VES measurements were carried out at one sounding point with electrode spacing varies from a small electrode distance to a large electrode 
gradually (Figure 3). The distance of the electrode will be proportional to the depth of the detected rock layer. The deeper the rock layer, the greater the electrode distance [7].

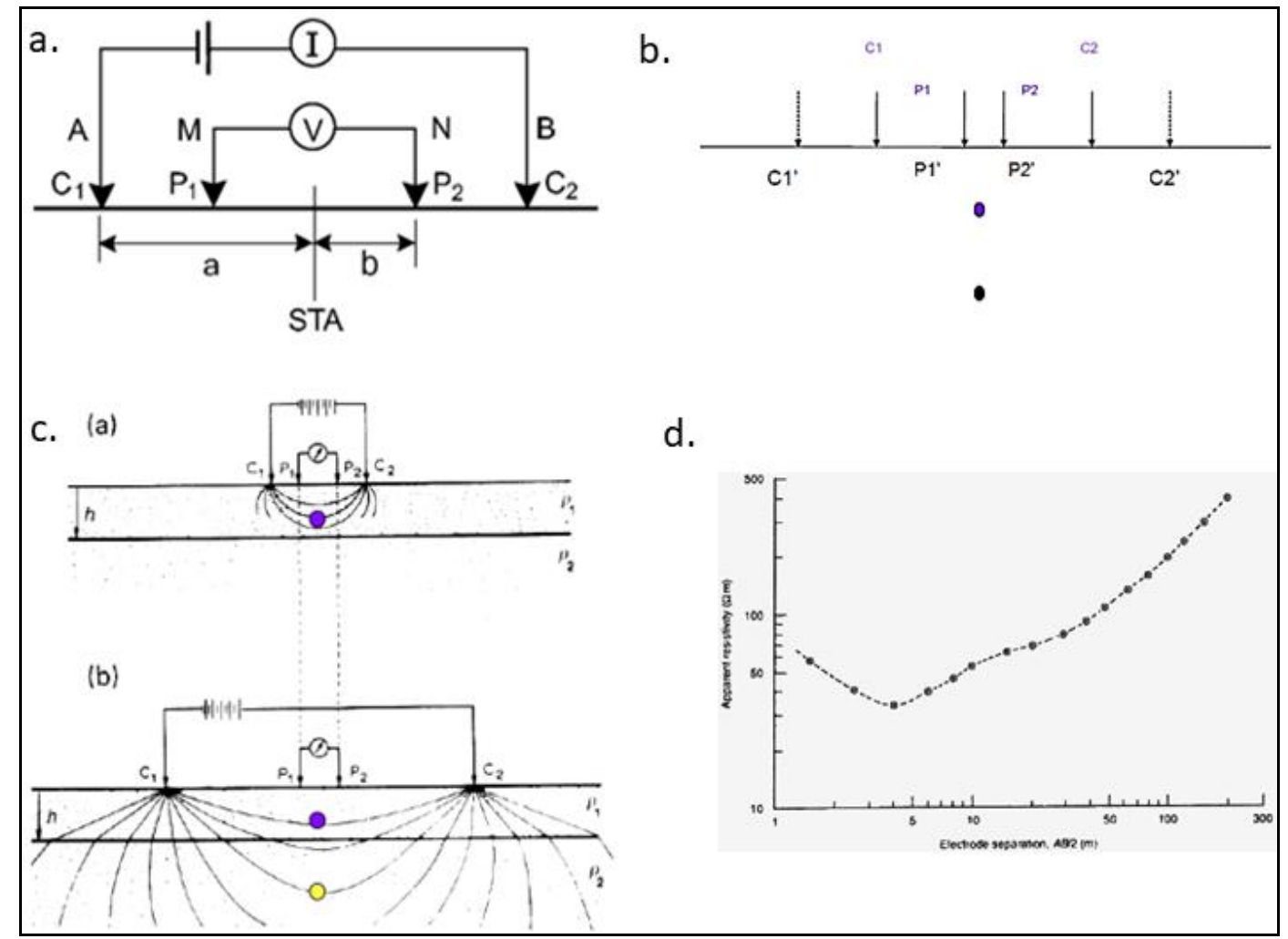

Figure 3. Flow measurement of VES

(a) determine configuration (b) determine the sounding point (c) measure at one sounding point with electrode spacing varies from the distance of the small electrode to the large electrode gradually (d) reconstruct $\mathrm{AB} / 2$ and $\rho$ a on the graph

The electrode configuration used in this study is Schlumberger configuration. In a Schlumberger configuration, the potential electrode distance $(\mathrm{MN} / 2)$ must be smaller than the current electrode distance $(\mathrm{AB} / 2)$, that is the value $\mathrm{MN} / 2<0.2 \mathrm{AB} / 2$. The distance of the current electrode $(\mathrm{AB} / 2)$ is enlarged to increase depth of penetration reading $\mathrm{MN} / 2$. If the potential difference is difficult to measure, the sensitivity of the tool decreases so that the potential electrode distance (MN / 2) must be enlarged [8]. The magnitude of the electric current and potential difference at each distance of the current electrode and potential electrode are recorded to calculate the apparent resistivity value of the subsurface rock. The apparent resistivity value is calculated using the formula:

$$
\rho_{\text {apparent }}=K \frac{\Delta V}{I}
$$

$\rho_{\text {apparent }}$ is apparent resistivity, $\Delta \mathrm{V}$ is a potential difference, $\mathrm{I}$ is an electric current, $\mathrm{K}$ is a geometry factor that depends on the electrode configuration. Because the electrode configuration used is Schlumberger configuration with the configuration equation is

$$
K=\pi\left(\frac{a^{2}-b^{2}}{2 b}\right)
$$

Qualitatively variations in resistivity to depth can be analyzed by sounding curves. Sounding curve is the result of ploting $\mathrm{AB} / 2$ with false resistivity values. Based on the sounding curve there are four types of sounding curves with variations in resistivity to depth for the case of three layers, namely type H, type A, type K and type Q (Figure 4). 


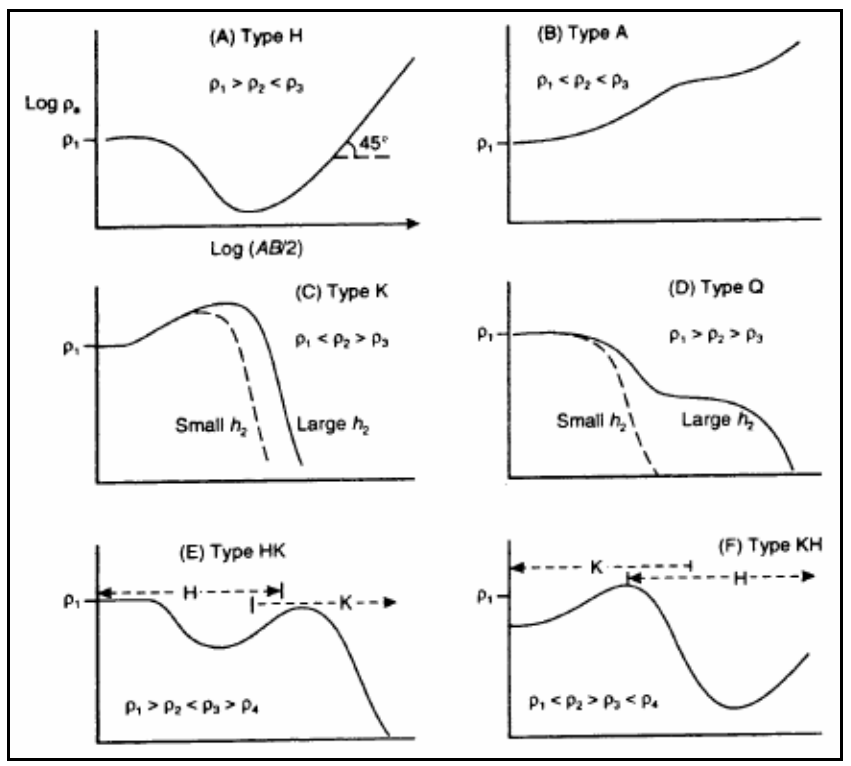

Figure 4. Sounding curve type [3]

\subsection{Regional Geology}

The research was conducted in the ITERA campus area. According to Mangga, et al (1993) [9], the ITERA campus is in the Lampung Formation (QTI) (Figure 5). The Lampung Formation is categorized as young which is quarterly in age, namely the transition of Pliocene and Plistocene. The Lampung Formation is dominated by one of rock unit, which is a product of volcanic activity, such as eruptions and deformation due to volcanism, tectonism or sedimentation. Volcanic rocks consist of pumiceous tuff, riolytic tuff, welded tuff tuffit, tuffaceous claystone and tuffaceous sandstones. Tuff is a product of volcanoes formed by eruption (either melt or eruption). The very fast formation process makes tuff has an open-packed, medium to good sorting and medium to high porosity. Because tuff has an open-packed, tuff has a high compressive strength ratio and is easy to brittle. Fragile rocks can affect the quality of the building or infrastructure on it.

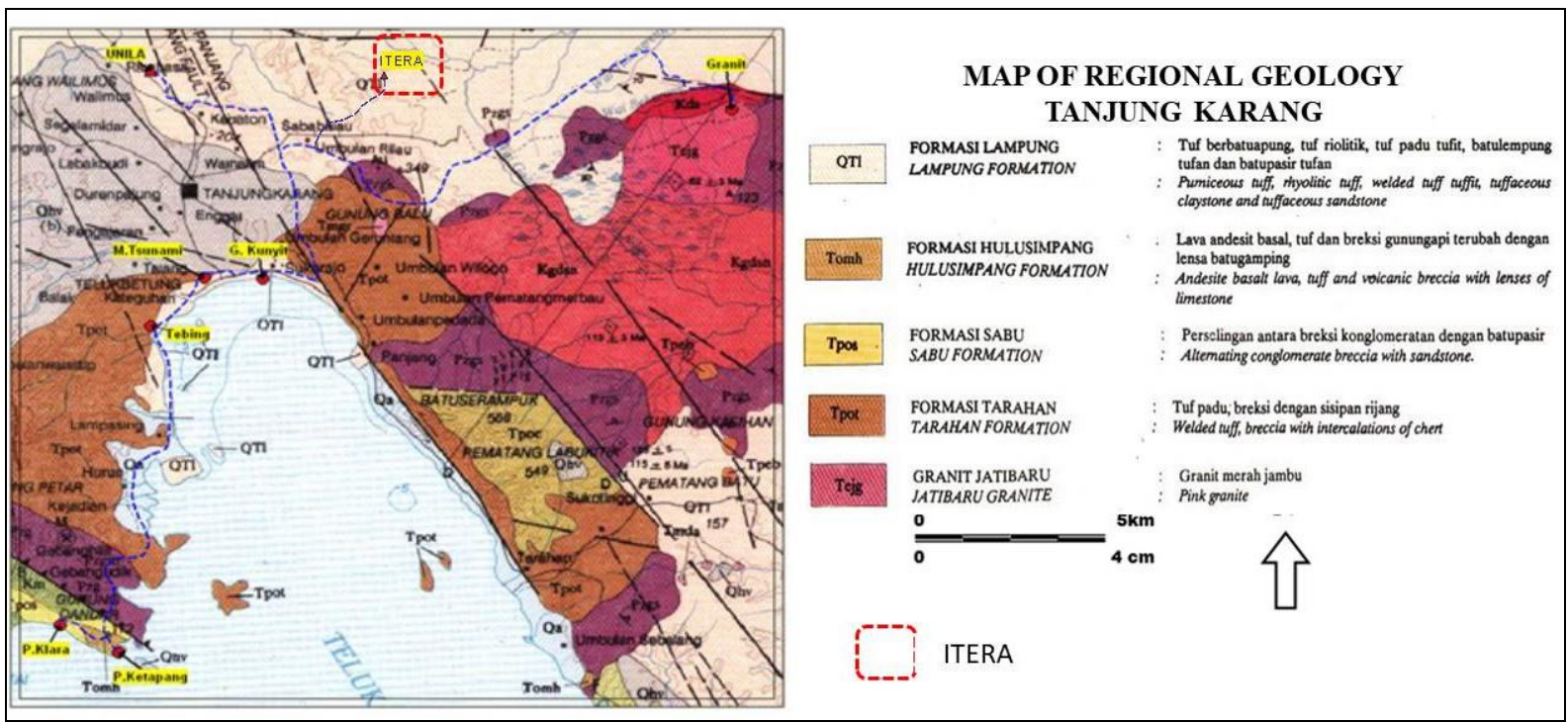

Figure 5. Map of Tanjung Karang Regional Geology [9]

\section{Vertical Electrical Sounding (VES)}


Vertical Electrical Sounding (VES) data acquisition is done by arranging electrodes using a Schlumberger configuration. The acquisition was carried out on 33 sounding points scattered on the ITERA campus around $\pm 150 \mathrm{Ha}$ (Figure 6). The direction of measurement from east to west with the measurement path length is made with varying $\mathrm{AB} / 2$ and $\mathrm{MN} / 2$ distances. Changes and variations of $\mathrm{MN} / 2$ and $\mathrm{AB} / 2$ are performed to obtain a vertical variation in subsurface resistivity from the surface to a depth of 150 meters. The minimum distance of $\mathrm{AB} / 2$ is 2 and the maximum distance of $\mathrm{AB} / 2$ is 150 meters while the $\mathrm{MN} / 2$ change is made of three (3) ie $0.5,2$ and 10 meters.

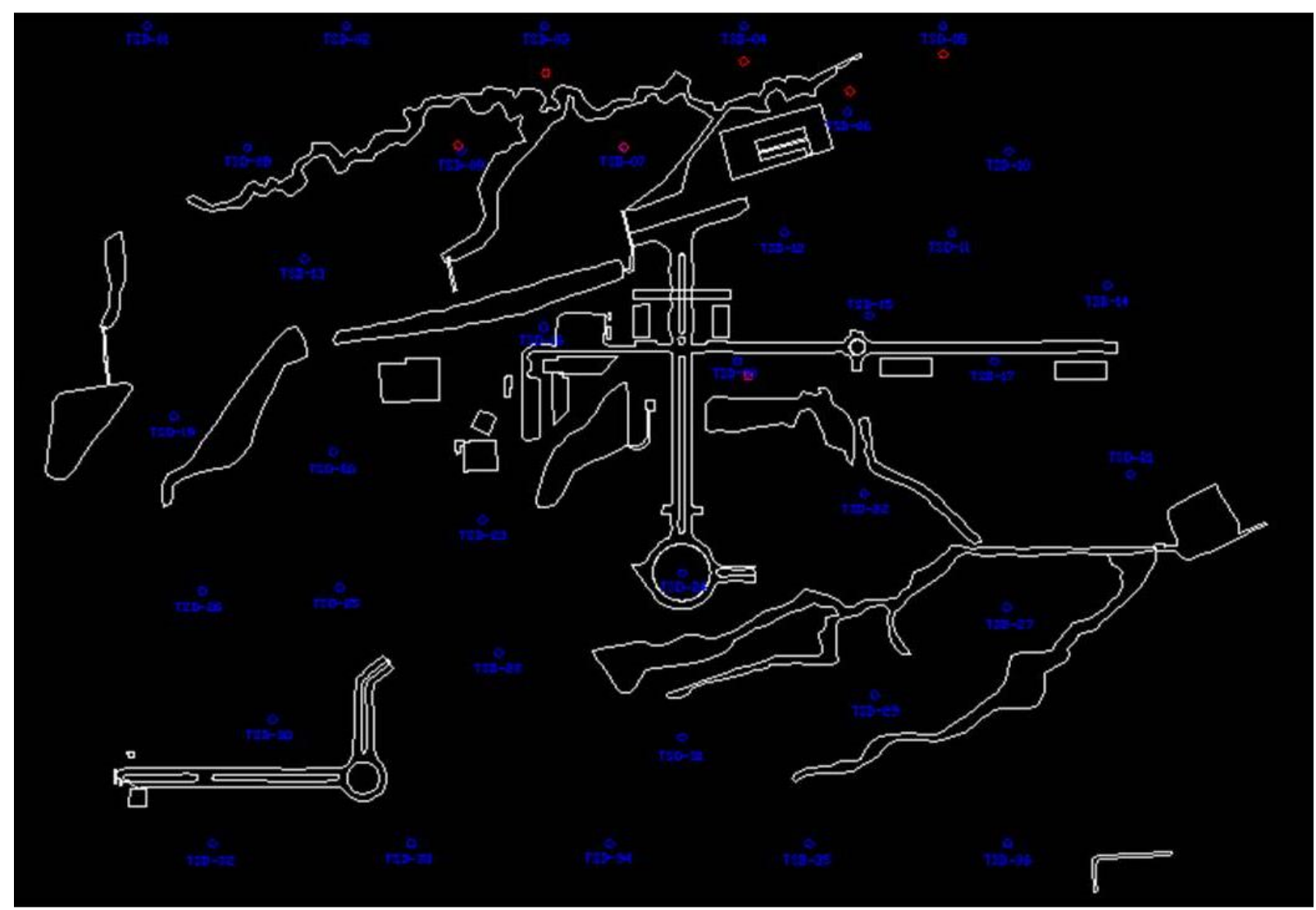

Figure 6. Distribution of the point of resistivity measurement ITERA

During the acquisition of the field, quality control is needed to obtain good data quality. The procedure is to ensure the contact resistance of the data obtained by the following procedure: (i) ensure low contact resistance between the electrodes and the ground measured by the instrument used; (ii) constructing the VES curve during field acquisition to avoid bad data points caused by leakage, or lateral effects in addition to electrode measurements; (iii) repeat measurements (repeatability) or change the location of electrodes to avoid the appearance of distortion or error data when measuring; (iv) Perform measurements that overlap on $\mathrm{AB} / 2$ values (for different $\mathrm{MN} / 2$ ) because different $\mathrm{MN}$ / 2 can cause a shift in the sounding curve segment. In this measurement, overlap was carried out at a distance of $\mathrm{AB} / 2$ are 8 meters and 50 meters. Furthermore, when the data processing stage with overlap measurement is also carried out correction of the curve segment shift to obtain a continuous curve. This is done by using a curve segment that overlaps with a small MN / 2 segment as a reference.

\section{Results and Discussions}

After doing resistivity measurements processing is done to get the subsurface model which is then interpreted to identify bedrock layers. Subsurface identification and rock estimation are determined 
based on resistivity values. Based on the resistivity value, i) sedimentary rocks which have low porosity and are easily destroyed have lower resistivity values compared to compact sedimentary rocks, ii) Igneous rocks and metamorphic rocks have relatively high resistivity values, iii) Permeable and water-containing rocks have resistivity values low.

Based on the results of 1D inversion data processing which has been correlated with local geological data, the ITERA campus has a resistivity value between $1-954 \Omega \mathrm{m}$. The resistivity value can be classified subsurface lithology based on differences in resistivity contrast values which can be seen in Table 1. Furthermore, the interpretation of subsurface lithology at each sounding point can be seen in Table 2.

Table 1. Resistivity Range of Research Location

\begin{tabular}{|l|l|}
\hline Resistivity Value & Lithology \\
\hline$<10 \Omega \mathrm{m}$ & tuffaceous claystone \\
\hline $10-<100 \Omega \mathrm{m}$ & tuffaceous sandstones \\
\hline$>100 \Omega \mathrm{m}$ & tuff \\
\hline
\end{tabular}

Table 2. Lithology Interpretation of the Subsurface

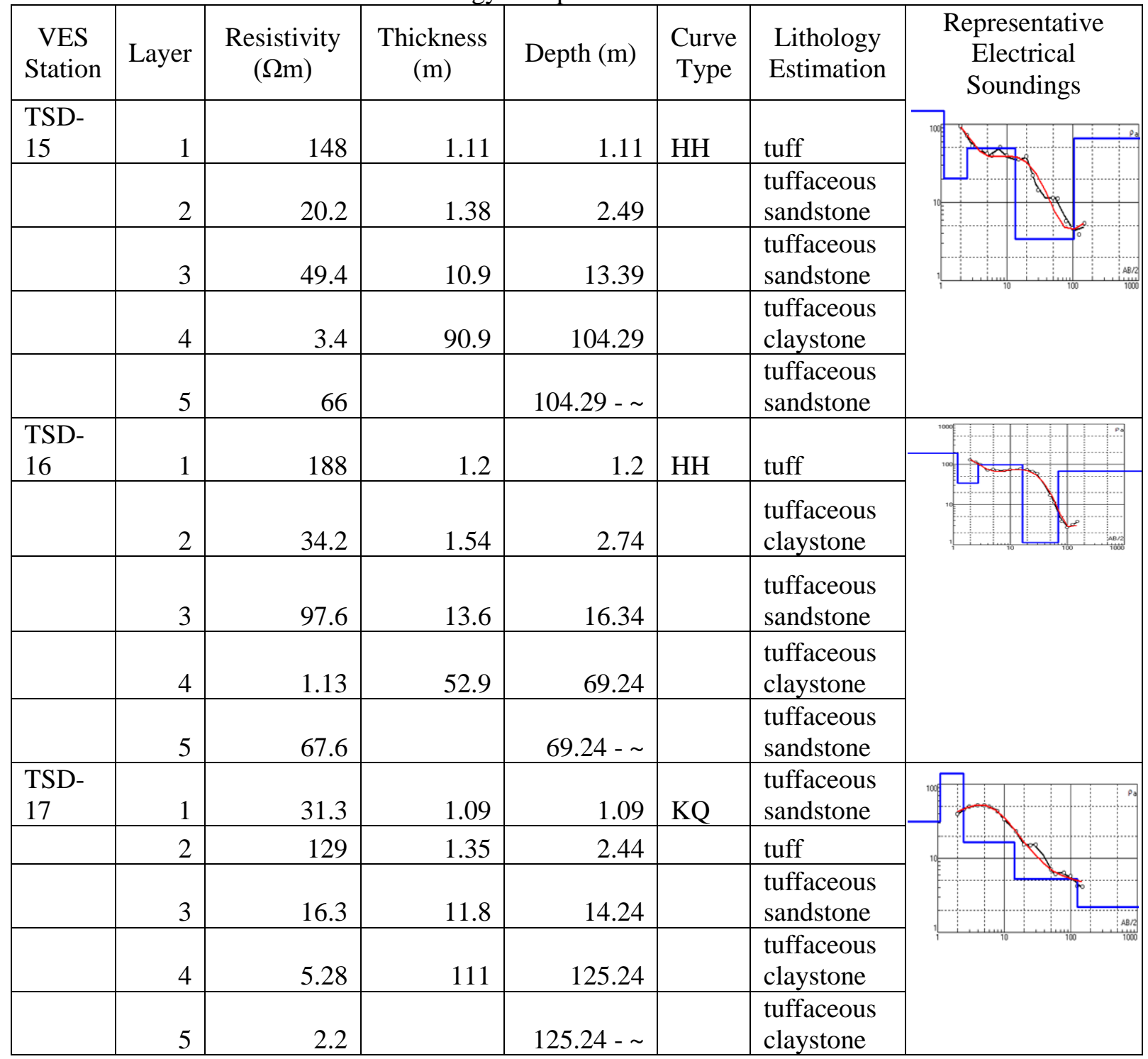


ICOSITER 2018 Proceeding

Journal of Science and Applicative Technology

\begin{tabular}{|c|c|c|c|c|c|c|c|}
\hline $\begin{array}{l}\text { TSD- } \\
18\end{array}$ & 1 & 153 & 1.45 & 1.45 & $\mathrm{HH}$ & tuff & 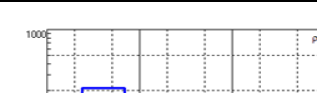 \\
\hline & 2 & 67.4 & 0.937 & 2.387 & & $\begin{array}{l}\text { tuffaceous } \\
\text { sandstone }\end{array}$ & ${ }^{\circ}+4$ \\
\hline & 3 & 211 & 4.49 & 6.877 & & tuff & \\
\hline & 4 & 12.3 & 77.8 & 84.677 & & $\begin{array}{l}\text { tuffaceous } \\
\text { sandstone }\end{array}$ & \\
\hline & 5 & 42.7 & & $84.677 \ldots$ & & $\begin{array}{l}\text { tuffaceous } \\
\text { sandstone }\end{array}$ & \\
\hline $\begin{array}{l}\text { TSD- } \\
19\end{array}$ & 1 & 213 & 2.74 & 2.74 & HQ & tuff & \\
\hline & 2 & 158 & 3.53 & 6.27 & & tuff & \\
\hline & 3 & 163 & 10.1 & 16.37 & & tuff & \\
\hline & 4 & 28.7 & 36.6 & 52.97 & & $\begin{array}{l}\text { tuffaceous } \\
\text { sandstone }\end{array}$ & 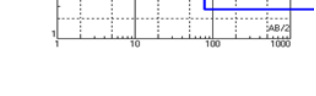 \\
\hline & 5 & 19.4 & 25.4 & 78.37 & & $\begin{array}{l}\text { tuffaceous } \\
\text { sandstone }\end{array}$ & \\
\hline & 6 & 2.73 & & $78.37-\sim$ & & $\begin{array}{l}\text { tuffaceous } \\
\text { claystone }\end{array}$ & \\
\hline $\begin{array}{l}\text { TSD- } \\
30\end{array}$ & 1 & 258 & 2.18 & 2.18 & HH & tuff & \\
\hline & 2 & 58.3 & 8.46 & 10.64 & & $\begin{array}{l}\text { tuffaceous } \\
\text { sandstone }\end{array}$ & \\
\hline & 3 & 94 & 14.8 & 25.44 & & $\begin{array}{l}\text { tuffaceous } \\
\text { sandstone }\end{array}$ & \\
\hline & 4 & 4.1 & 44.9 & 70.34 & & $\begin{array}{l}\text { tuffaceous } \\
\text { claystone }\end{array}$ & \\
\hline & 5 & 64.7 & & $70.34-\sim$ & & $\begin{array}{l}\text { tuffaceous } \\
\text { sandstone }\end{array}$ & \\
\hline $\begin{array}{l}\text { TSD- } \\
32\end{array}$ & 1 & 230 & 1.76 & 1.76 & HQ & tuff & \\
\hline & 2 & 24.8 & 5.17 & 6.93 & & $\begin{array}{l}\text { tuffaceous } \\
\text { sandstone }\end{array}$ & \\
\hline & 3 & 84.2 & 10.2 & 17.13 & & $\begin{array}{l}\text { tuffaceous } \\
\text { sandstone }\end{array}$ & $\underbrace{}_{\substack{i=0 \\
\text { ind }}}$ \\
\hline & 4 & 11 & 59.1 & 76.23 & & $\begin{array}{l}\text { tuffaceous } \\
\text { sandstone }\end{array}$ & \\
\hline & 5 & 3.57 & & $76.23-\sim$ & & $\begin{array}{l}\text { tuffaceous } \\
\text { claystone }\end{array}$ & \\
\hline $\begin{array}{l}\text { TSD- } \\
33\end{array}$ & 1 & 954 & 0.57 & 0.57 & $\mathrm{HH}$ & tuff & \\
\hline & 2 & 108 & 17.8 & 18.37 & & tuff & \\
\hline & 3 & 110 & 2.29 & 20.66 & & tuff & \\
\hline & 4 & 7.04 & 105 & 125.66 & & $\begin{array}{l}\text { tuffaceous } \\
\text { claystone }\end{array}$ & $\omega_{i \infty}$ \\
\hline & 5 & 171 & & $125.66-\sim$ & & tuff & \\
\hline $\begin{array}{l}\text { TSD- } \\
35\end{array}$ & 1 & 89.9 & 1.2 & 1.2 & $\mathrm{KH}$ & $\begin{array}{l}\text { tuffaceous } \\
\text { sandstone }\end{array}$ & \\
\hline & 2 & 142 & 1.54 & 2.74 & & tuff & \\
\hline
\end{tabular}




\begin{tabular}{|r|r|r|r|r|r|r|} 
& 3 & 11.9 & 9.32 & 12.06 & & $\begin{array}{l}\text { tuffaceous } \\
\text { sandstone }\end{array}$ \\
\hline & 4 & 3.47 & 58.2 & 70.26 & & $\begin{array}{l}\text { tuffaceous } \\
\text { claystone }\end{array}$ \\
\hline & 5 & 66 & & $70.26 \sim$ & $\begin{array}{l}\text { tuffaceous } \\
\text { sandstone }\end{array}$ \\
\hline
\end{tabular}

\subsection{Isoresistivity map}

An isoresistivity map is a map that describes resistivity values at the same depth. In this study, the author made an isoresistivity map of the ITERA campus (Figure 7) with the apparent distribution of type $\mathrm{AB} / 2$ prisoners at a depth of $2.5 \mathrm{~m}, 5 \mathrm{~m}, 10 \mathrm{~m}$ and $15 \mathrm{~m}$. At a depth of $2.5 \mathrm{~m}$ there is a resistivity value ranging from $0-320 \Omega \mathrm{m}$. Low resistivity value $(<10 \Omega \mathrm{m})$ which is suspected to be tuffaceous claystone and medium $(10-<100 \Omega \mathrm{m})$ which is assumed to be tuffaceous sandstone in the middle area of ITERA (zone A). Tuffaceous claystone and tuffaceous sandstone are still found at a depth of $5 \mathrm{~m}$ and slowly change to resistivity values to be large $(>100 \Omega \mathrm{m})$ at a depth of $10 \mathrm{~m}$ and $15 \mathrm{~m}$. Large resistivity values are thought to be tuff rocks which become bedrock.

In the middle to south area of ITERA (zone B) has a high resistivity value $(>100 \Omega \mathrm{m}$ ) which is thought to be a tuff rock that becomes bedrock. Bedrock can be found to a depth of 15 meters. Because tuff rock is a rock that is good as a bedrock, heavy building construction with a depth of 5-15 meters can be constructed in zone $\mathrm{B}$.

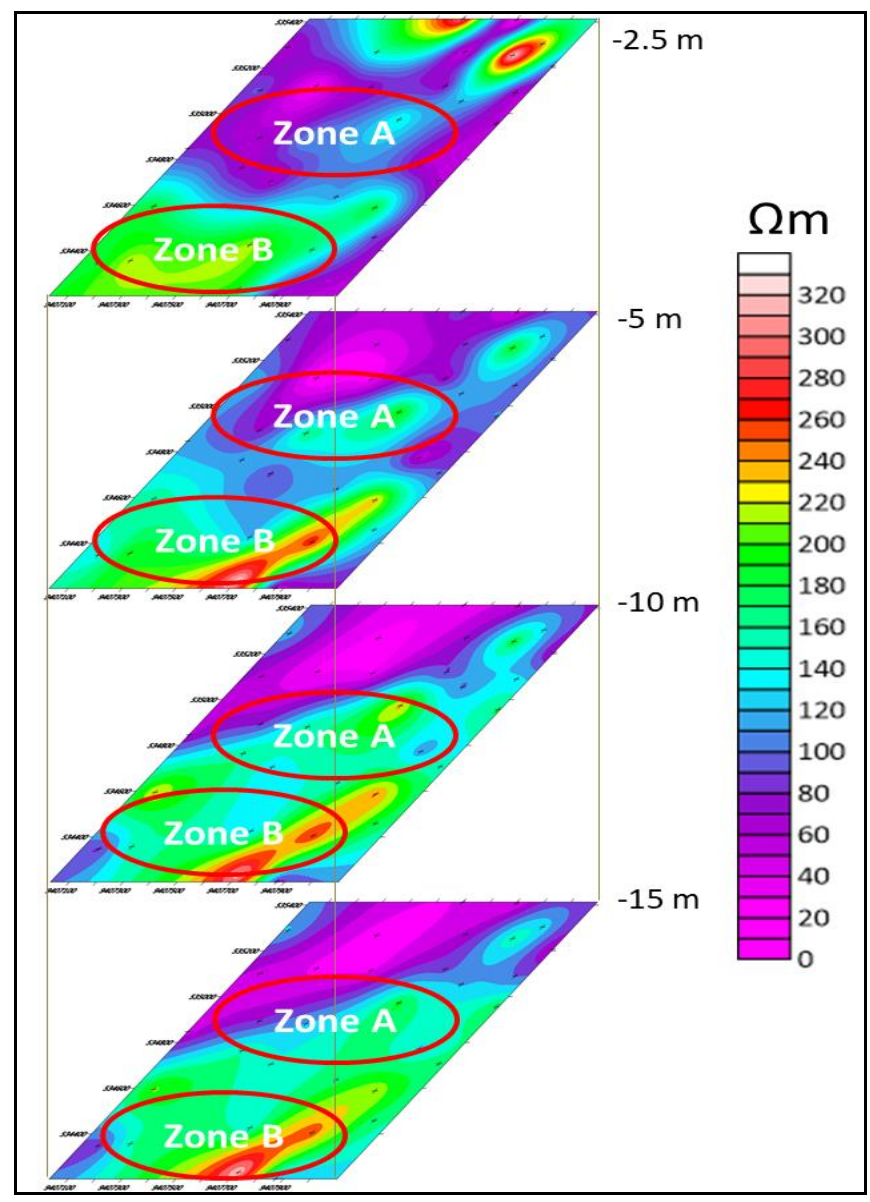

Figure 7. Isoresistivity map 


\subsection{Lithological analysis and correlation of sounding points}

Zone $\mathrm{A}$ is in the central area of the ITERA campus In this area there has been a lot of development on the ITERA campus. Based on the cross section resistivity of the sounding point TSD19, TSD16, TSD18, TSD15, TSD17 found layered rocks (Figure 8). The top layer at the sounding point TSD19, TSD16, TSD18, TSD15 found rocks that have high resistivity values $(>100 \Omega \mathrm{m})$. This rock is thought to be tuff rock. This tuff rock is very thick $(10 \mathrm{~m})$ at the point of TSD19. But on TSD16, TSD18, TSD15 tuff layer thinned to $1 \mathrm{~m}$ on TSD17. Tuff rock is massive, has medium sorting, impermeable and openly packed. Because of the impermeable and massive nature of the rock, tuff rock can be a bedrock that is good for heavy building construction foundations (buildings that have> 3 levels). So that a heavy building foundation can be built in zone A with a depth of $10 \mathrm{~m}$ at TSD19.

Below the tuff layer is found rock that has a resistivity value in $10-<100 \Omega \mathrm{m}$ which is thought to be tuffaceous sandstone. The tuffaceous sandstone is very thick $(>15 \mathrm{~m})$ at the sounding point TSD19 then the thinning tuffaceous sandstone on TSD16 then disappears and pores on TSD18. Then the tuffaceous sandstone appears again thinly on TSD15 and TSD17. Tuffaceous sandstone is a sedimentary rock that has high porosity and is permeable. Tuffaceous sandstone also has elastic properties and is not cohesive (so that it is not binding), so that if construction is built on it will cause a decrease in tuffaceous sand. Tuffaceous sandstone lacks the strength to hold heavy buildings. Because of that tuffaceous sand layers are better used for buildings with light construction. If you want to build heavy construction on the tuffaceous sandstone layer, the foundation must be made deeper to hold the building. Because TSD16, TSD18, TSD15 has thin tuff rocks and underneath is tuffaceous sandstone, then at these points should be constructed light construction. If heavy construction is to be built, it must make a foundation $>10 \mathrm{~m}$ for the safety of the building.

In TSD17, rocks with low resistivity values $(<10 \Omega \mathrm{m})$ were found to be tuffaceous claystone. Tuffaceous claystone under tuff and thin tuffaceous sandstone has a thickness of $>10 \mathrm{~m}$ on TSD17. Tuffaceous claystone has good and permeable porosity. Tuffaceous claystone is soft rock which consists of very small grains. If there is a large construction load, it will cause foundation damage or deterioration which causes the construction to not function. As a result the soil surface around the construction will rise or fall. Tuffaceous claystone are also susceptible to liquefaction. So that layers that have thick tuffaceous claystone can only be used for the construction of light construction with light loads (building <3 levels). For ITERA, the authors suggest that the area around TSD17 (west region of ITERA) should not be used for development and is better used for greening areas.

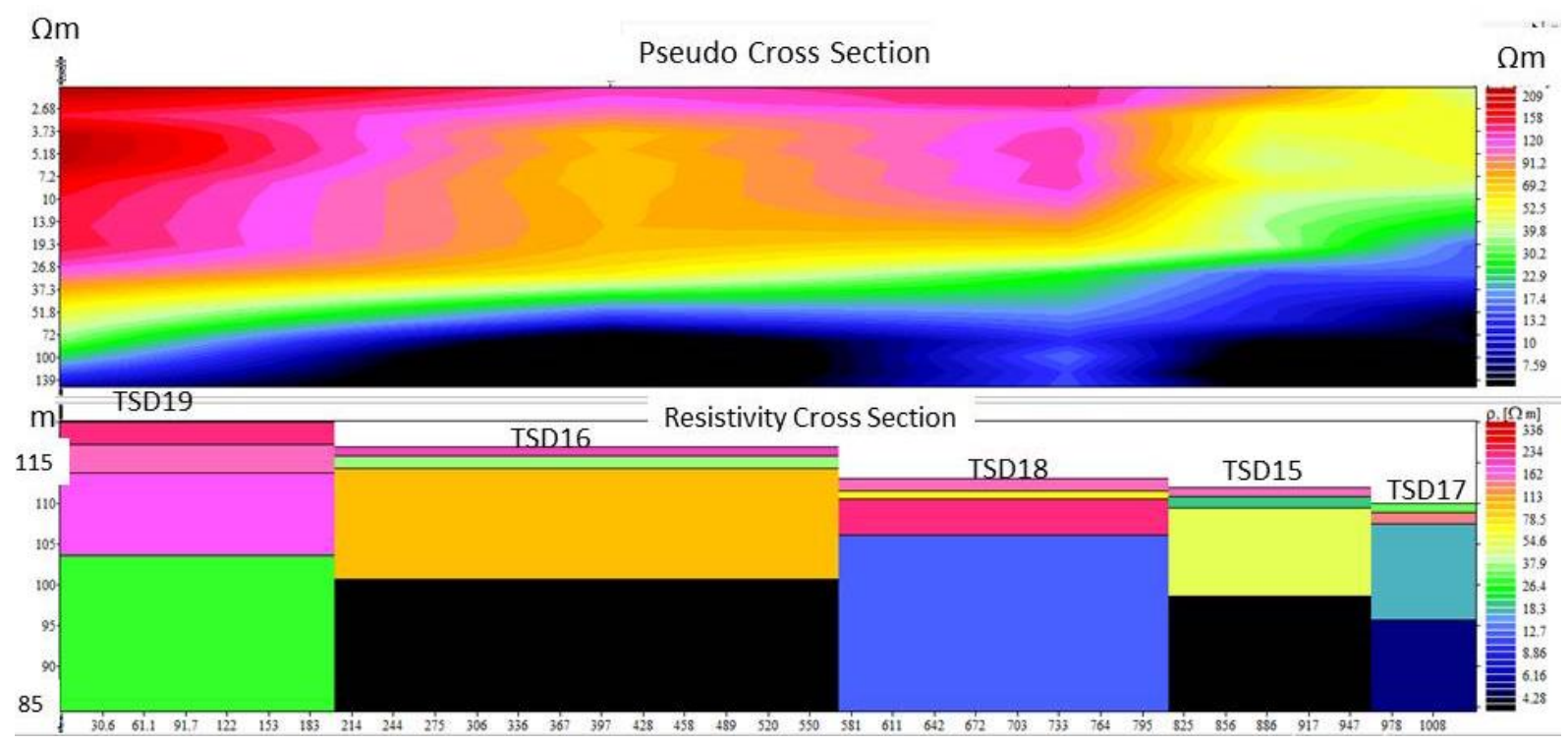

Figure 8. Lithology model and correlation of zone A sounding points 
Zone B is a zone that has not been developed at ITERA and is recommended for development. Based on the cross section resistivity of the sounding point TSD32 and TSD30 (Figure 9), at the top layer of zone B there is a high resistivity value $(>100 \Omega \mathrm{m})$ with a thickness of $\pm 10 \mathrm{~m}$ which is thought to be rock tuff and bedrock at the TSD32 and TSD30 points. However, at the sounding points of TSD33 and TSD35 tuff rocks begin to disappear. Tuff rock has a massive, impermeable and openpacked rock. So that tuff rocks are very good for heavy construction constructions. So for the heavy construction can already be built at the point TSD30 and TSD32 with a depth of 10 meters.

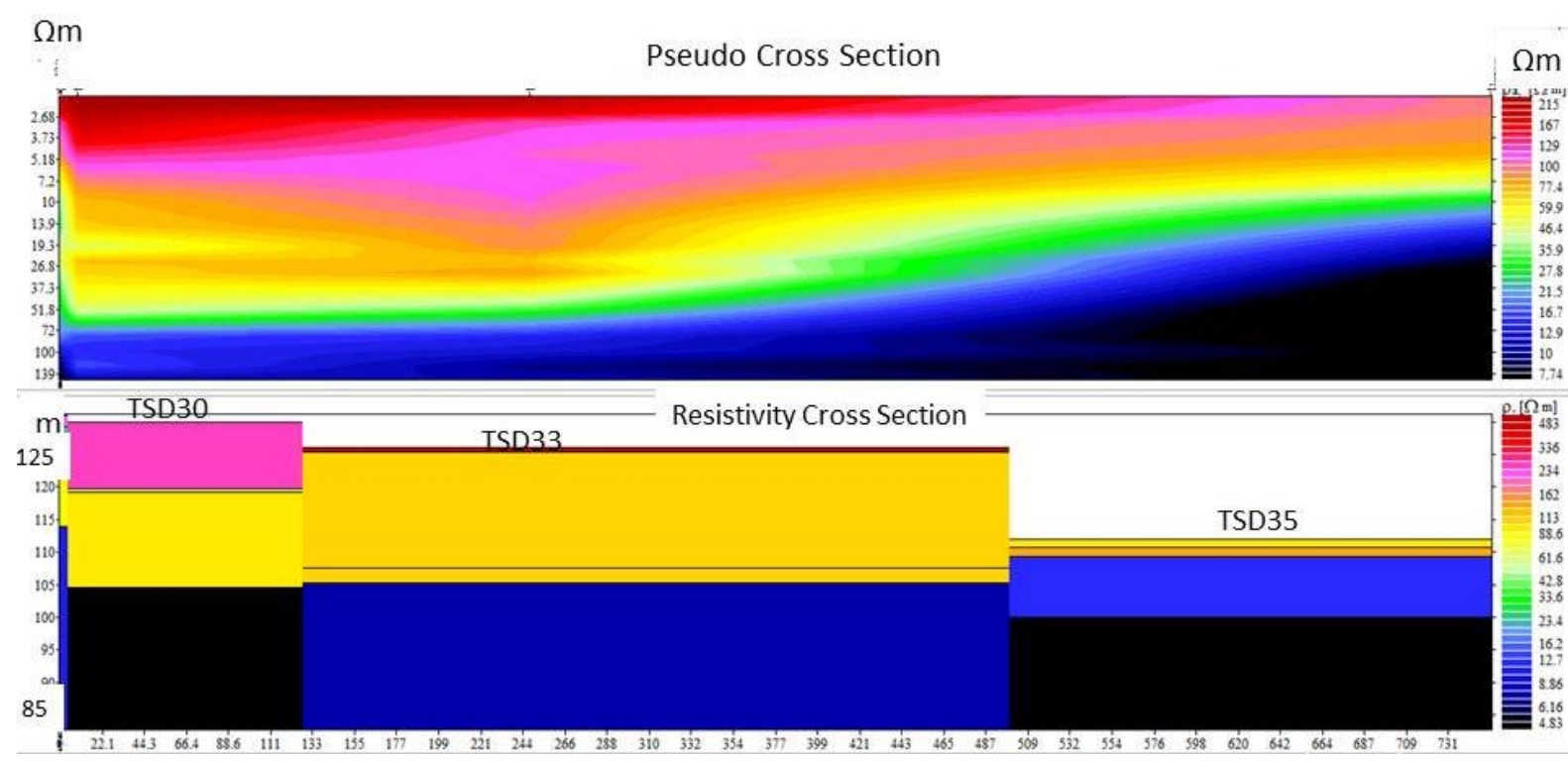

Figure 9. Lithology model and correlation of zone B sounding points

The top layer of the TSD33 sounding point is found rock which has a resistivity value $(10-<100$ $\Omega \mathrm{m})$ with a thickness of $\pm 15 \mathrm{~m}$. This rock is thought to be tuffaceous sandstone. Tuffaceous sandstone is the continuity of rock in the second layer TSD30 and TSD33. Tuffaceous sandstone was also found in the top layer of TSD35 even though the TSD35 tuffaceous sandstone was thought to be very thin $( \pm 1 \mathrm{~m})$. Tuffaceous sandstone properties and composition are more inclined to tuff and are good rocks used for heavy construction. So that the TSD33 can also be built in heavy construction to a depth of 10-15 m.

The TSD35 sounding point located on the west only has a thin tuffaceous sandstone layer while underneath is found rock with a low resistivity value $(<10 \Omega \mathrm{m})$. This rock has a low resistivity value which is thought to be tuffaceous claystone. Tuffaceous claystone are not good for heavy construction and can only be used for light construction. So that the area around TSD35 (western part of ITERA) should be used to build light construction. But even more interesting this area is used only for green areas.

\section{Conclusion}

Based on the results of 1D resistivity inversion ITERA campus arranged on the rock layers that compose it. Based on the resistivity value correlated with the geological map, the ITERA campus is composed of tuff rock (resistivity value $>100 \Omega \mathrm{m}$ ), tuffaceous sandstone (resistivity values $10-<100$ $\Omega \mathrm{m})$, and tuffaceous claystone $(<10 \Omega \mathrm{m})$. Based on the iso-resistivity and resistivity map, the cross section of the east area of ITERA has thick tuff. Tuff becomes bedrock which can be used for heavy construction construction. But the west area of ITERA has thick soft rock (tuffaceous claystone) and can be used for light construction or greening areas. 


\section{Acknowledgement}

We thank you to LP3 ITERA to providing the funding for these research. Also to Lab Geoscience for the resistivity instrument to acquire the data.

\section{References}

[1] Fotheringham, 2013, Comparison of Geophysical Techniques to Determine Depth to Bedrock in Complex Weathered Environments of the Mount Crawford Region, South Australia, The University of Adelaide.

[2] Samouelian, et al. 2005. Electrical resistivity survey in soil science: a review, Soil and Tillage Research, vol. 83, no. 2, pp. 173-193.

[3] Saminu, O. 1999. Geophysical Investigation of Federal College of Education, Zaria. Unpublished M.Sc. Thesis, Department of Physics, Ahmadu Bello University, Zaria.

[4] Puradimaja, D. J., 2006, Tingkatkan akurasi data dan informasi geologi bawah permukaan. Acara Peringatan Hari Bumi dan Peluncuran Jurnal Geoaplika. FIKTM, ITB.

[5] Schepers R, Rafat G, Gelbke C, Lehman B. 2001. Application of borehole logging, core imaging and tornography of geotechnical exploration. Intl $\mathbf{J}$ of Rock Mech and Mni Sci Elsevier 38: 867-876.

[6] Loke, M.H., 2000, Electrical Imaging Survey for Environmental and Engineering Studies

[7] Reynolds, J.M., 2005, Principles of Applied Geophysics. Cambridge University Press, Cambridge.

[8] Telford, M.W., Geldart, L.P., Sheriff, R.E., dan Keys, D.A., 1990, Applied Geophysics, Cambridge Univ Press

[9] Mangga, S. A., Amirudin., Suwarti, T.,Gafoer, S., \& Sidarto., 1993, Peta Geologi Lembar Tanjungkarang, Sumatera. Bandung. 